\title{
Waste-to-Hope: Measuring Sustainability Benefits of Product Philanthropy Partnership
}

\author{
Oral S. Saulters*, Brijesh Krishnan, Mary Beth Harris, Hani Bashour, Laura Bellows, \\ Evan J. Ringquist, Diane Henshel
}

School of Public and Environmental Affairs, Indiana University, Bloomington, IN, USA

Email: *osaulter@indiana.edu

How to cite this paper: Saulters, O.S., Krishnan, B., Harris, M.B., Bashour, H., Bellows, L., Ringquist, E.J. and Henshel, D. (2017) Waste-to-Hope: Measuring Sustainability Benefits of Product Philanthropy Partnership. Journal of Environmental Protection, 8, 1219-1242.

https://doi.org/10.4236/jep.2017.810076

Received: August 25, 2017

Accepted: September 25, 2017

Published: September 28, 2017

Copyright $\odot 2017$ by authors and Scientific Research Publishing Inc. This work is licensed under the Creative Commons Attribution International License (CC BY 4.0).

http://creativecommons.org/licenses/by/4.0/

\begin{abstract}
This study investigates the sustainability-related impacts of the Framing Hope program, an innovative private and nonprofit sector partnership between the nonprofit Good360 and The Home Depot. Specifically, this paper estimates the energy savings, landfill space not filled, and the energy- and landfill-related cost savings associated with the Good360 product philanthropy program with The Home Depot, illustrating that benefits accrue to both company and communities by linkages between environmental, socioeconomic, and energy dimensions. Findings suggest that by redirecting products from the waste stream into usable community resources, considerable landfill space, costs, and energy savings were realized. Product donations can serve as an important platform for sustainable community development and capacity building. This research adds to the growing body of knowledge on environmental performance, corporate giving, and cross-sector partnerships in sustainable and social entrepreneurship.
\end{abstract}

\section{Keywords}

Sustainability, Product Philanthropy, Corporate Social Responsibility

\section{Introduction}

Sustainable development and sustainability-related initiatives have become increasingly important considerations for communities, organizations, and cross-sector collaborations [1] [2] [3] [4]. Many of these efforts involve partnerships between private and nonprofit organizations [5] [6]. Beyond intuitive and anecdotal notions of "win-win" benefits, there is a growing body of research assessing the performance outcomes of these corporate/nonprofit collaborations for nonprofits and their clients, increasingly within the context of social entre- 
preneurship [7]-[15]. Similarly, research and community outreach addressing social justice and equity within ecological limits, for all stakeholders, is being integrated into "just sustainabilities" decision making perspectives [16].

This study examines the impact of the Framing Hope Product Donation program for nonprofit organizations on local community sustainability. Initial work was conducted in a pilot phase [17] followed by subsequent analysis. As one of the first investigations of this type, this research specifically evaluates environmental and energy dimensions of product philanthropy. To begin unpacking the multidimensional effects of the Framing Hope program on community sustainability, three research questions were addressed: What are the landfill volume and tipping cost savings? What are the manufacturing energy savings? What are the energy consumption savings?

\section{Product Philanthropy and Corporate Social Responsibility}

Corporate philanthropy has a long and controversial history including involvement of American industry titans such as Andrew Carnegie, Henry Ford, and J.D. Rockefeller. For example, Carnegie stressed a duty to the most beneficial results for the community when the more common neoclassical approach emphasized strict obligation to shareholders [18] [19] [20]. Corporate philanthropy is driven by various motives including instrumental reasons for profit maximization, political legitimacy, and altruistic efforts for social responsibility [21] [22] [23]. Today Carnegie's perspective is labeled "Corporate Social Responsibility" (CSR). In its early modern incarnation, CSR was described as "the obligations of businessmen to pursue those policies, to make those decisions, or to follow those lines of action which are desirable in terms of the objectives and values of our society" [24]. More recently, Carroll has described CSR as a pyramid: the foundation is economically based (i.e., be profitable); followed by legal requirements (obey the law); ethical responsibilities (do no harm); and ultimately at the apex, the philanthropic responsibility to contribute resources to the community [25]. In recent years, companies of all sizes and classifications have been implementing CSR and related initiatives with differing motivations, approaches, and outcomes [26]-[32]. In particular, sustainability and shared value programs have been increasing; many of these programs include substantial charitable donations and intentional partnerships with nonprofit organizations [33] [34] [35] [36] [37]. With more than 1.5 million nonprofit organizations in the US, there are tremendous opportunities for robust collaborations of this sort [38] [39] [40].

\subsection{Product Philanthropy as an Element of Corporate Social Responsibility}

Philanthropic giving is an important component of most CSR strategies. By one estimate, over the past forty years corporate giving has grown from $\$ 0.85$ billion in 1971 to $\$ 14.56$ billion in 2010 [41] (see Figure 1). 


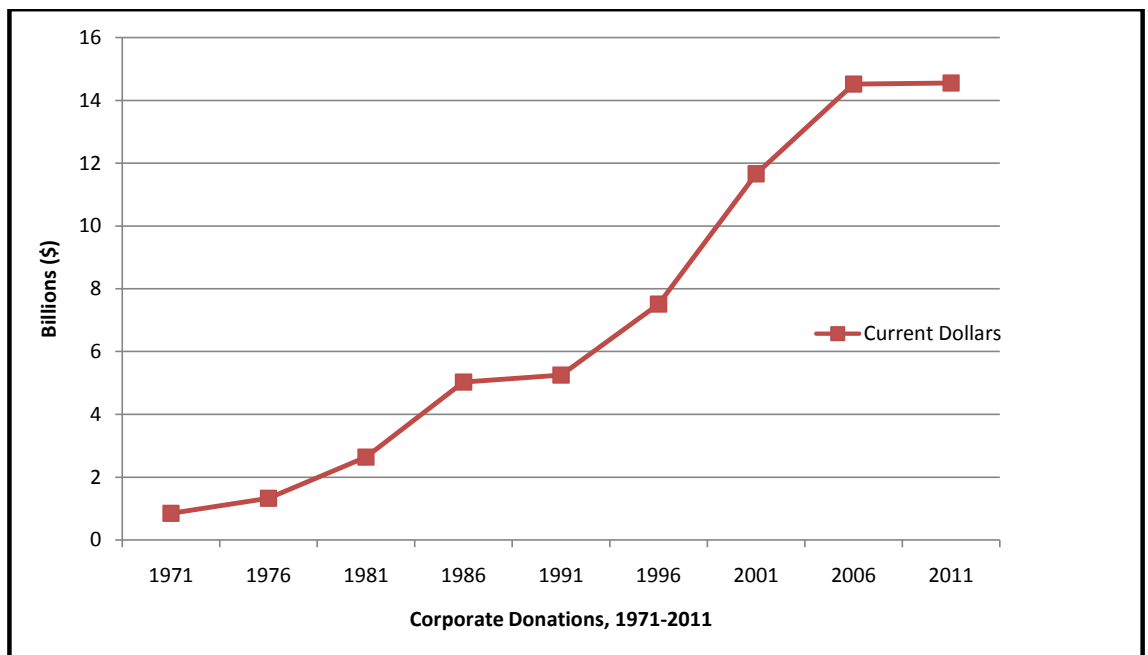

Figure 1. Estimated Trend in Corporate Giving, 1971 - 2011 (Adapted from Giving USA 2012).

A sizeable proportion of philanthropic donations are in the form of monetary contributions from corporations and grants and gifts made by corporate foundations. At the same time, a majority of these donations take the form of noncash in-kind contributions made through corporate giving programs. In-kind contributions characterize direct or indirect non-cash donations of pro-bono services or products assessed at fair market value [41].

Corporate product donations represent a subset of all in-kind giving, distinct from any other corporate gifts of time and expertise. Product donations involve many diverse goods such as food, pharmaceutical and health care products, computer equipment, and other retail products [42]. Product donation programs are becoming an increasingly popular component of corporate management systems. As shown in Figure 2, pharmaceutical companies have been the largest contributors of in-kind giving in recent years, followed by computer equipment and information technology service companies. In fact, eight of the top ten corporate donors come from these two industries [43].

Product donations by private businesses represent an important source of support for nonprofits and have contributed meaningfully to the expansion of programs in national nonprofit organizations [44]. Despite the importance of corporate product donations, the value of in-kind donations has not been consistently measured over time [41]. Among the top 20 corporate donors in Figure 2 , the value of product donations equaled nearly $\$ 12$ billion, and product donations accounted for 81.5 percent of all corporate giving. This degree of corporate product philanthropy may not be typical, however. Data from 110 large companies show that while corporate giving increased 23 percent between 2007 and 2010, product donations increased at a much faster rate and accounted for approximately 60 percent of corporate giving during this period [45] see Figure 3).

Four factors help account for the recent increase in product donations: 1) Firms are replacing cash donations with product philanthropy during highly 


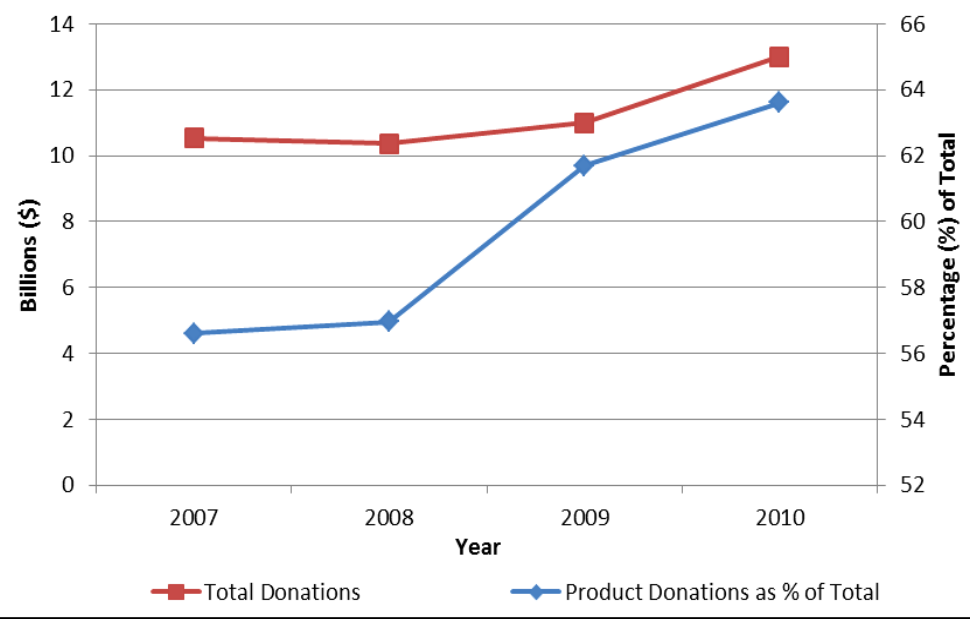

Figure 2. Survey of Corporate Giving and Product Donations (Adapted from CECP, 2011).

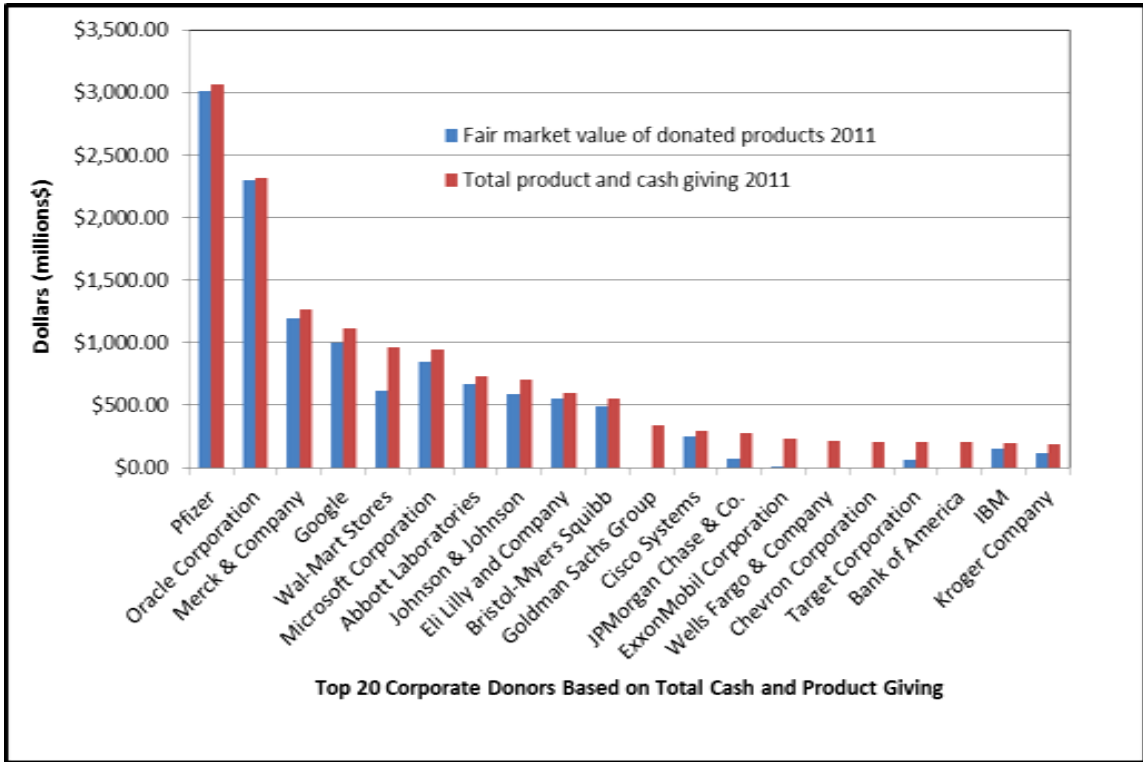

Figure 3. Top 20 Corporate Donors Based on Total Cash and Product Donations (Adapted from Chronicle of Philanthropy, 2012).

uncertain economic conditions that tend to generate excess inventory and lower cash balances; 2) Product donations are more visible in the long-term; 3) Product donation is a more environmentally sustainable option over landfill disposal; and 4) companies can capture financial advantages from the special tax treatment of product donations [46] (Figure 4).

\subsection{An Example of Corporate Product Philanthropy: Framing Hope}

Started in 2008, Framing Hope is a collaboration between The Home Depot, The Home Depot Foundation, Good360 (the nation's largest nonprofit specializing in product donations), and local nonprofit organizations. In 2010, Good360 


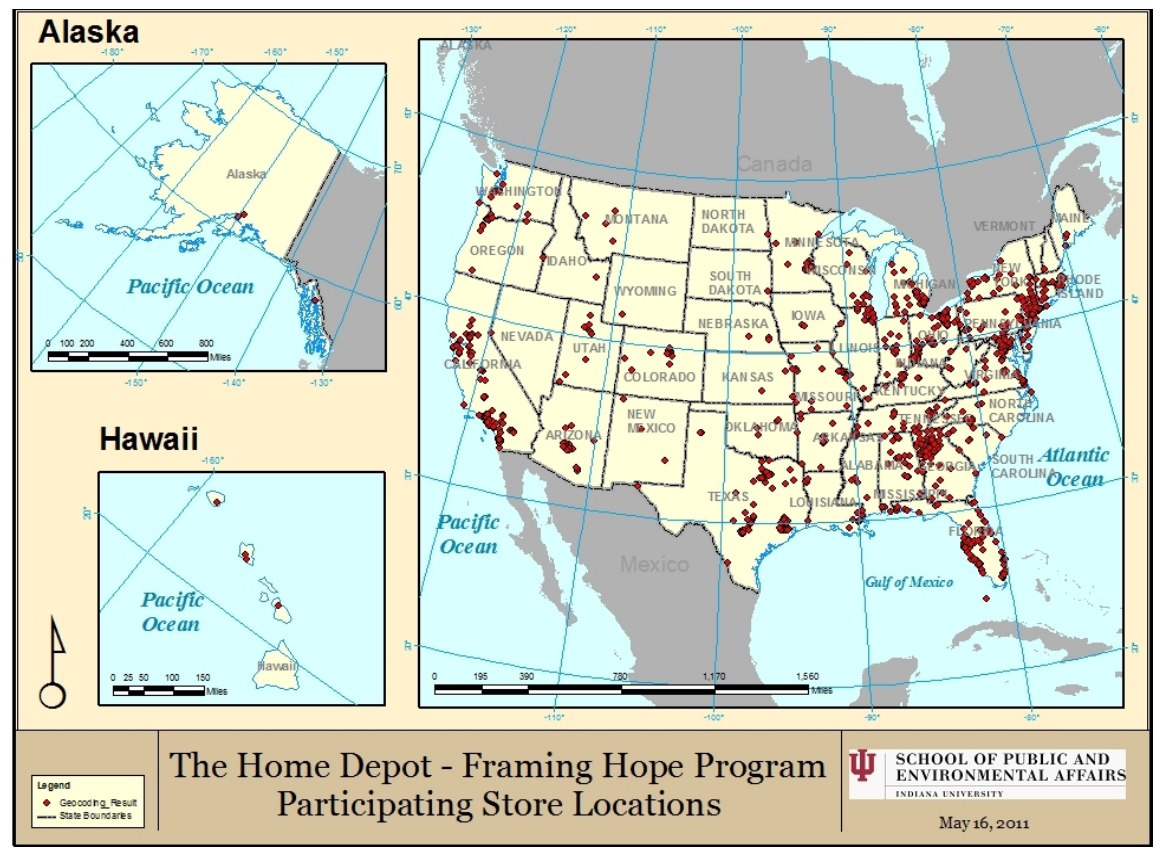

Figure 4. Framing Hope Program Locations in the United States.

handled more than $\$ 350$ million in product donations from dozens of corporate partners. Through Framing Hope, The Home Depot stores are matched with nonprofits in their given communities. The nonprofits must be 501(c) (3) organizations and are required to go through an application and screening process to determine their eligibility. The nonprofit organizations must agree to use the products for charitable purposes and not sell, trade, barter, or auction any of the donations in accordance with Federal Tax Code 170(e)3, using the products only to help the poor, the sick, and children. The nonprofit organizations must provide support in housing/homelessness, youth/senior housing, civic/cultural issues, community re-building, revitalization, renovation or other similar projects [47]. In engaging in the partnership, the nonprofits must be willing to accept the products donated by the stores on a weekly basis. Depending on the particular store's retail activities and inventory, the products can range widely from week to week. One week the items may include bathroom fixtures, hammers, and an assortment of rugs; the following week, products may be doors, windows, and lumber. Guidance information and training are offered to help nonprofit organizations make use of and share items.

Based on initial success, the program was expanded in 2009 to offer more opportunities for smaller nonprofit organizations to participate that might not have the staff and infrastructure capacity to support the weekly pickups, storage, and use of all donated products. Therefore, the program launched the Framing Hope Warehouse Strategy in larger communities with higher volume to connect The Home Depot stores, large nonprofit organizations with the logistical capability to redistribute the products, and smaller nonprofit organizations. By the end of 2012, Good360 had matched The Home Depot stores in over 1000 com- 
munities with more than 1200 local nonprofit organizations to receive product donations [47]. Through these partnerships, The Home Depot had donated more than 10 million items with a fair market value of $\$ 150$ million to nonprofit social service organizations in local communities.

\section{Assessing the Effects from Corporate Product Philanthropy}

Product donations through Framing Hope are a central element of The Home Depot's corporate philanthropy and CSR strategies. In addition, product donations like those made through Framing Hope embody the "triple bottom line" perspective on corporate sustainability efforts in that they may benefit companies, strengthen local communities, and protect and improve the quality of the environment. Despite the magnitude of product donations and their potential to impact each element of the "triple bottom line," there has been virtually no effort to evaluate the sustainability-related benefits of product donations for companies, communities, or the environment. Furthermore, because the Framing Hope program represents one company partnering with many nonprofit organizations, it offers a uniquely specific and central source of data that enable a quantitative evaluation of these sustainability-related benefits of the program.

\subsection{Effects for Companies}

The analysis of the business case for the Framing Hope program suggests that in-kind philanthropy is a prudent process that can benefit both the corporation and civil society including recipient nonprofit organizations [46]. Product donations are generally more financially beneficial than cash donations because of the special IRS tax deduction pursuant to Tax Code $\delta 170(\mathrm{e})(3)$. Beyond financial grounds, there are other advantages to product donations over cash donations such as targeted visibility because of the direct pathway to end users rather than being used to cover administrative expenses by nonprofits, a concern evaluated by charity-rating groups like Charity Watch [43]. Other benefits are derived from the relative transaction simplicity for both companies and their nonprofit partners.

Strategic product donation programs can enhance corporate image by "signaling" to stakeholders and complementing advertising and marketing efforts. With a strong public image, employees can demonstrate stronger commitment and trust [33] [48]. Product donation programs can attract new talent, customers, and investors as consumers are demanding more product philanthropy and social purpose [49]. Moreover, these ventures can support a business friendly environment by establishing legitimacy with stakeholders including regulatory agencies and local governments which tend to grant greater latitude to firms with such socially responsible programs [46] [50]. Another set of key relationships in product donation collaborations are those with intermediary nonprofits such as Good360 and the National Association for the Exchange of Industrial Resources (NAEIR). Intermediaries, with their extensive logistical and charity 
networks, can provide cost advantages through assistance in matching, lowering administrative costs, simplifying logistics, ensuring brand security, and gaining positive media coverage. Generally, it is recommended that corporations research individual intermediaries carefully before engaging in partnerships to explore potential organizational compatibility and mission fit.

\subsection{Effects for Communities}

A survey and follow-up evaluation of the Framing Hope effects on organizational partners estimated that over 450,000 households benefitted from the program with a multimillion dollar value of received products [34]. The study found that over $60 \%$ of nonprofits share the donated products with other organizations. Challenges were noted with participating charity capacity such as excess inventory, transportation, storage, and lack of performance measures. Many nonprofits were able to leverage product donations to start new programs, expand services, and obtain additional funding by using the products as a match for grant requirements. Another key finding included in Gazley and Abner [33] (relates to the need for improving corporate communications of program objectives with local stores and improving training of employees to support those goals. Local context matters, as Paarlberg and Meinhold [51] have found with the United Way's nationwide Community Impact program; there can be significant variation in implementation and allocation practices at the community level driven by local logics. Further research on the complex nexus between organizational capacity and performance outcomes in the context of product philanthropy remains an important area of investigation.

According to the Consumer Expenditure Survey [52], people in lower economic groups spend a significantly higher percentage of their income on expenditure categories such as energy and utilities, housekeeping supplies, and household furnishings, areas directly related to products donated through the Framing Hope Program. Even small corporate donations can contribute substantively to household budgets. With almost no information in the research literature on the effects of product donations on meeting the needs of families and individual end users, Seefeldt and Abner [52] conducted a pilot case study to gather baseline data. The researchers noted the complexities in identifying, coordinating, and conducting interviews of Framing Hope end users. Their brief analysis addressed recipients as both organizations and individuals. For the nonprofits, donated products facilitated less dependence on financial donations and streamlined completion of service projects. For low-income individual end users, product philanthropy fostered self-sufficiency, provided higher quality products than thrift stores, and enhanced community life through empowerment for home improvements and social interactions at the neighborhood level [52]. This research suggests that while most scholarly efforts have focused on top down processes and estimated effects, empirical studies of actual stakeholders are needed to improve metrics of program impacts and performance dimensions. 


\subsection{Effects on the Environment}

In evaluating the impacts from the sustainability triple bottom line, the final perspective, environmental outcomes, remained unknown. This paper begins to address the data gap. The remainder of this paper presents the three approaches used to quantify the sustainability-related benefits of the Framing Hope program, focusing particularly on environmental and social benefits. The two environmental benefits considered include landfill space preserved by not putting the reused products in landfills and the energy saved both in manufacturing the reused materials and energy saved by the receiving community, assuming that these products either replaced less energy efficient models or enabled behavioral energy savings. Cost savings associated with reduced landfill tipping fees and the cost of energy produced are also quantified. The paper concludes with a discussion of the results, placing this analysis within the context of the social entrepreneurship and social capitalism literature that uses a Blended Value approach to quantifying the social impacts of philanthropy and social entrepreneurship.

\section{Measuring the Environmental Benefits of Framing Hope}

\subsection{Research Goals and Guiding Questions}

The goal for this work was to assess the environmental and related social benefits gained by removing the donated Home Depot products from the waste stream and facilitating their reuse by donating them to nonprofits (for community redistribution) through the Framing Hope program.

Three questions guided this research: 1) How much volume is saved in landfills and what is the cost saved? 2) What is the embodied energy saved for products not manufactured? 3) How much energy are consumers saving by using the donated products that are designated energy efficient?

\subsection{Data Sources, Verification, and Processing}

Data were provided by Good360 and The Home Depot. The Home Depot has the SKU (stock keeping unit as unique identifier) of each donated product and through its Framing Hope web portal, allows integrated tracking, reporting, and verification functions to be performed. Data on donated products from February 1, 2008 through May 31, 2010 were evaluated. During this period, nearly 4.7 million products were donated representing 57,341 SKUs, worth approximately $\$ 64.7$ million. Additionally, The Home Depot provided information on the dimension and weight of some products, although only 51.2 percent were reported in the data. The Home Depot also provided information on the make and model for certain products with energy usage value; however, only not all products had this information available. Finally, The Home Depot also provided their three tiered classification system for SKUs to assist with identifying products. After merging the two datasets, The Home Depot datasets were checked to ensure that there were no SKUs with inconsistent information (for example, lumber that was donated in different lengths). 


\subsection{Quantifying the Environmental Benefits of Donated Products}

In 2010, Americans generated nearly 250 million tons of municipal solid waste with roughly 35 to 45 percent coming from commercial and institutional sources [53]. Approximately 136 million tons of waste (54.2 percent of total) was disposed of in landfills in 2010, down from nearly 89 percent of waste generated in 1980. Before the Framing Hope program was established in 2008, most of the returned, unsold, displayed, overstocked, and discontinued products ended up in local landfills. Many of the products donated through Framing Hope are building supplies and materials, plumbing products, assorted household and cleaning items. These types of products are often used for construction and renovation activities, and result in construction and demolition (C \& D) debris-a type of solid waste that tends to be larger and is particularly disparate in form, physical characteristics, and materials [54]. Construction and demolition debris is state rather than federally regulated. The state programs vary widely in terms of legal definitions and management requirements [55] [56]. Organizations such as the U.S. Agency for Toxic Substances and Disease Registry (ATSDR) and federal, state, and local partners have noted community health and worker safety concerns with C\&D landfills including those derived from the generation of hydrogen sulfide emissions associated with the decomposition of gypsum drywall and organic debris [57] [58] [59].

The nearly 14 tons of items donated through the Framing Hope program represent an important opportunity for product philanthropy. By shifting these products from waste streams into useful product resources, community sustainability can be improved in multiple ways. As an initial quantitative estimation of the sustainability impact of diverting these products, we quantified preserved landfill space (a community benefit), the cost savings associated with not putting these products in landfills (a business benefit), the energy embodied in these products through the manufacturing process (a global benefit), and the energy saved as well as the cost of energy saved by the receiving community members who were given energy efficient (USEPA Energy Star program) appliances and other materials that either replaced less energy efficient appliances or products or encouraged energy saving behaviors (e.g., using a fan; a community benefit).

1) Question \#1a: How Much Volume Is Saved in Landfills by Removing the Donated Products from the Waste Stream?

Like many retail stores, The Home Depot disposed of much of its excess inventory as solid waste. This practice contributed to the disposal of new and useable products, consumption of valuable landfill space, and resulted in financial expenditures for waste management, fees, and future liability. The Framing Hope program provides a distinct, more sustainable alternative to disposal of these unwanted products.

The Home Depot database included data on relevant product characteristics including quantity, weight, and dimensions. Complete product information including dimensions, needed to estimate volume, and weight were available for 
only about half of the donated products. To fill in the gaps, the 57,341 products were sorted into 23 categories based on key material types (see Table 1). Within each of the individual categories, based on known weights, volumes, and quantities, average values and total values for the categories were calculated. Missing dimensions and weight values were estimated based on the averages for similar products.

Four assumptions were made about the data. 1) All products were indeed diverted from landfills. 2) Product SKUs were unique identifiers for products. 3) The product categories accurately classify individual items. 4) The reference data for each category was representative enough to fill in missing values of weight and volume. Using these assumptions, the total weight for the donated products was estimated to be 13,913 tons.

To calculate the total landfill volume of donations, the actual expected landfill volume had to be estimated from the volume calculated from the product dimensions. Most products are compacted before being put into landfills [60] [61]

Table 1. Product Categories and Number of Stock Keeping Units (SKUs).

\begin{tabular}{|c|c|c|}
\hline Category \# & Category Name & Number of SKUs \\
\hline 1 & Additives \& Adhesions & 209 \\
\hline 2 & Batteries & 90 \\
\hline 3 & Cement Based Products & 252 \\
\hline 4 & Ceramic Materials & 2127 \\
\hline 5 & Construction Chemicals & 421 \\
\hline 6 & Construction Materials & 451 \\
\hline 7 & Construction Natural Materials & 517 \\
\hline 8 & Electrical \& Electronic Products & 9705 \\
\hline 9 & Electrical Cables \& Wires & 654 \\
\hline 10 & Fiberglass & 424 \\
\hline 11 & Glass Products & 667 \\
\hline 12 & Metal Plastic Products & 3464 \\
\hline 13 & Metal Plastic Wood Products & 1498 \\
\hline 14 & Metal Products & 18,552 \\
\hline 15 & Metal Rubber Products & 305 \\
\hline 16 & Natural Products & 2622 \\
\hline 17 & Organic Products & 1498 \\
\hline 18 & Paints & 62 \\
\hline 19 & Paper Cardboard Products & 282 \\
\hline 20 & Plastic Products & 6402 \\
\hline 21 & Rubber Products & 562 \\
\hline 22 & Wood Furniture & 2202 \\
\hline 23 & Wood Products & 4375 \\
\hline
\end{tabular}


[62]. To determine the landfill volume saved, a final post-compression landfill volume had to be calculated, based on the ratio between the pre-compaction density $\left(157 \mathrm{lbs} / \mathrm{yd}^{3}\right)$ and the target post-compaction density $\left(700 \mathrm{lbs} / \mathrm{yd}^{3}\right.$; a value provided by a Republic Services representative in Indiana). The estimated compression ratio used (1:4.456) was then applied to the initial volume using the following equation:

Total Volume Reduced $=$ Total Volume of Products ${ }^{*}$ Compression Ratio (Equation (1))

The total initial volume for the donated products was estimated to be $4,782,820 \mathrm{ft}^{3}$. The estimated reduction in volume of landfill space was determined to be $1,073,271 \mathrm{ft}^{3}$ or $39,751 \mathrm{yd}^{3}$.

2) Question \#1b: What Is the Cost Saved By Not Putting These Products in Landfills? Tipping costs are dependent on weight. To arrive at total tipping costs saved by Framing Hope, the total product weight was multiplied by the per-ton tipping cost ( $\$ 43.99$ per ton, reported by Republic Services) per the following equation:

Total Cost Savings $=$ Total Weight of Products ${ }^{*}$ Tipping Fee (Equation (2))

Using the average tipping fee of $\$ 43.99 /$ ton, and the total calculated weight of 13,913 tons, the total tipping fee cost savings was $\$ \mathbf{6 1 2 , 0 2 3}$.

A second calculation method used to enhance the accuracy of our results integrated more micro-level information, including geospatial data. Specifically, the physical location of individual Home Depot stores and their community nonprofit partners that participated in the program were used to estimate location specific cost savings. Hierarchical aggregation was employed for the donated product information (weight and volume data) at each store location and across each state. The actual tipping fees (averaged across surveyed locations) for each state were identified [63] and used to calculate total cost savings at the state level. In addition, a more current typical average compaction target density of $1200 \mathrm{lbs} / \mathrm{yd}^{3}$ (used for C\&D waste and roughly 70\% higher than the initial density identified by Republic Services in Indiana) was used [64] to calculate the landfill volume effectively offset. Table 2 summarizes the state level results. These yielded overall cost savings of $\$ 559,645$ and volume savings of $626,075 \mathrm{ft}^{3}$ or $21,188 \mathrm{yd}^{3}$.

3) Question \#2: What Is the Energy Saved for Products Reused?

\section{Recovering Energy Embodied in Product Donations}

Another important measure of the impact of the Framing Hope program involves accounting for the total sum of lifecycle energy flows required to produce the donated products. When products are used and consumed, on a fundamental level energy is being transformed and used. Energy analysis is an attempt to estimate how much energy is required to provide goods and services. A key aspect of energy analysis is determining the embodied energy which is the total (direct and indirect) energy required for the production of economic or environmental goods and services [64]. 
Table 2. Tipping Fees, Weights, and Volumes of Donated Products for Each State.

\begin{tabular}{|c|c|c|c|c|}
\hline State & $\begin{array}{c}\text { Tipping Fee } \\
\text { (\$/Ton) }\end{array}$ & $\begin{array}{c}\text { Weight } \\
\text { (lbs) }\end{array}$ & $\begin{array}{c}\text { Volume } \\
\left(\mathrm{in}^{3}\right)\end{array}$ & $\begin{array}{c}\text { Total Cost } \\
(\$)\end{array}$ \\
\hline $\mathrm{AK}$ & 43.83 & $4.90 \mathrm{E}+04$ & $1.28 \mathrm{E}+07$ & 1073 \\
\hline $\mathrm{AL}$ & 25 & $3.28 \mathrm{E}+05$ & $9.60 \mathrm{E}+07$ & 4095 \\
\hline $\mathrm{AR}$ & 35 & $1.35 \mathrm{E}+05$ & $3.92 \mathrm{E}+07$ & 2360 \\
\hline $\mathrm{AZ}$ & 29.24 & $4.75 \mathrm{E}+05$ & $1.41 \mathrm{E}+08$ & 6944 \\
\hline $\mathrm{CA}$ & 43.83 & $2.34 \mathrm{E}+06$ & $8.81 \mathrm{E}+08$ & 51331 \\
\hline $\mathrm{CO}$ & 30.47 & $1.87 \mathrm{E}+05$ & $5.28 \mathrm{E}+07$ & 2851 \\
\hline $\mathrm{CT}$ & 63 & $1.37 \mathrm{E}+05$ & $4.01 \mathrm{E}+07$ & 4328 \\
\hline DC & 55.45 & $2.61 \mathrm{E}+04$ & $8.10 \mathrm{E}+06$ & 724 \\
\hline $\mathrm{DE}$ & 58.9 & $4.48 \mathrm{E}+04$ & $9.72 \mathrm{E}+06$ & 1319 \\
\hline $\mathrm{FL}$ & 37 & $2.66 \mathrm{E}+06$ & $6.86 \mathrm{E}+08$ & 49,139 \\
\hline GA & 34.92 & $2.74 \mathrm{E}+06$ & $8.37 \mathrm{E}+08$ & 47,771 \\
\hline HI & 43.83 & $8.48 \mathrm{E}+04$ & $1.67 \mathrm{E}+07$ & 1859 \\
\hline IA & 40.71 & $5.24 \mathrm{E}+04$ & $1.23 \mathrm{E}+07$ & 1066 \\
\hline ID & 46.16 & $1.20 \mathrm{E}+04$ & $3.78 \mathrm{E}+06$ & 278 \\
\hline IL & 35.5 & $8.23 \mathrm{E}+05$ & $2.56 \mathrm{E}+08$ & 14,606 \\
\hline IN & 29.57 & $5.06 \mathrm{E}+05$ & $1.50 \mathrm{E}+08$ & 7476 \\
\hline KS & 30 & $1.76 \mathrm{E}+05$ & $5.00 \mathrm{E}+07$ & 2640 \\
\hline $\mathrm{KY}$ & 29.21 & $3.17 \mathrm{E}+05$ & $8.25 \mathrm{E}+07$ & 4632 \\
\hline LA & 46 & $2.29 \mathrm{E}+05$ & $6.16 \mathrm{E}+07$ & 5278 \\
\hline MA & 72 & $4.76 \mathrm{E}+05$ & $1.23 \mathrm{E}+08$ & 17,144 \\
\hline $\mathrm{MD}$ & 52 & $1.73 E+06$ & $5.48 \mathrm{E}+08$ & 45,051 \\
\hline $\mathrm{ME}$ & 60 & $6.30 \mathrm{E}+04$ & $1.81 \mathrm{E}+07$ & 1891 \\
\hline MI & 34.7 & $1.10 \mathrm{E}+06$ & $2.99 \mathrm{E}+08$ & 19,121 \\
\hline MN & 50 & $2.30 \mathrm{E}+05$ & $6.38 \mathrm{E}+07$ & 5756 \\
\hline MO & 33.73 & $2.93 \mathrm{E}+05$ & $8.51 \mathrm{E}+07$ & 4942 \\
\hline MS & 25 & $9.94 \mathrm{E}+04$ & $3.45 \mathrm{E}+07$ & 1242 \\
\hline MT & 42 & $3.04 \mathrm{E}+04$ & $7.67 \mathrm{E}+06$ & 639 \\
\hline NC & 35 & $3.87 \mathrm{E}+05$ & $9.70 \mathrm{E}+07$ & 6773 \\
\hline ND & 34 & $4.05 \mathrm{E}+03$ & $8.72 \mathrm{E}+05$ & 69 \\
\hline $\mathrm{NE}$ & 39.14 & $1.15 \mathrm{E}+05$ & $2.94 \mathrm{E}+07$ & 2259 \\
\hline $\mathrm{NH}$ & 77 & $4.20 \mathrm{E}+04$ & $1.01 \mathrm{E}+07$ & 1618 \\
\hline NJ & 68 & $5.23 \mathrm{E}+05$ & $1.38 \mathrm{E}+08$ & 17767 \\
\hline $\mathrm{NM}$ & 28 & $1.90 \mathrm{E}+05$ & $3.99 \mathrm{E}+07$ & 2663 \\
\hline NV & 35 & $9.56 \mathrm{E}+03$ & $2.53 \mathrm{E}+06$ & 167 \\
\hline NY & 44.69 & $2.15 \mathrm{E}+06$ & $6.31 \mathrm{E}+08$ & 47998 \\
\hline $\mathrm{OH}$ & 32 & $2.08 \mathrm{E}+06$ & $6.47 \mathrm{E}+08$ & 33221 \\
\hline
\end{tabular}




\section{Continued}

\begin{tabular}{ccccc}
\hline OK & 18.5 & $1.63 \mathrm{E}+05$ & $3.13 \mathrm{E}+07$ & 1506 \\
OR & 35 & $5.91 \mathrm{E}+05$ & $2.00 \mathrm{E}+08$ & 10,339 \\
PA & 48.37 & $2.29 \mathrm{E}+06$ & $6.68 \mathrm{E}+08$ & 55,404 \\
RI & 52 & $5.04 \mathrm{E}+04$ & $1.46 \mathrm{E}+07$ & 1309 \\
SC & 35 & $2.59 \mathrm{E}+05$ & $6.76 \mathrm{E}+07$ & 4532 \\
SD & 39.5 & $6.71 \mathrm{E}+04$ & $1.67 \mathrm{E}+07$ & 1326 \\
TN & 34 & $7.50 \mathrm{E}+05$ & $2.16 \mathrm{E}+08$ & 12,748 \\
TX & 27.8 & $9.89 \mathrm{E}+05$ & $2.69 \mathrm{E}+08$ & 13,745 \\
UT & 37.82 & $1.67 \mathrm{E}+05$ & $5.15 \mathrm{E}+07$ & 3161 \\
VA & 40.35 & $6.89 \mathrm{E}+05$ & $2.40 \mathrm{E}+08$ & 13,903 \\
VT & 96 & $5.19 \mathrm{E}+03$ & $1.21 \mathrm{E}+06$ & 249 \\
WA & 52.65 & $4.85 \mathrm{E}+05$ & $1.47 \mathrm{E}+08$ & 12,758 \\
WI & 42.5 & $3.59 \mathrm{E}+05$ & $9.77 \mathrm{E}+07$ & 7635 \\
WV & 45.18 & $8.17 \mathrm{E}+04$ & $2.27 \mathrm{E}+07$ & 1847 \\
WY & 55 & $3.97 \mathrm{E}+04$ & $1.11 \mathrm{E}+07$ & 1091 \\
Totals & & $2.78 \mathrm{E}+07$ & $8.27 \mathrm{E}+09$ & 559,645 \\
\hline
\end{tabular}

4) The Input-Output Analysis Approach to Life Cycle Assessment

Because of the significant amount and diverse variety of products donated, measuring the embodied energy presented a formidable research challenge. After review of the lifecycle assessment literature including ISO 14040 and 14044 standards, we realized that the scope of this effort was unprecedented [65] [66] [67]. With the wide range of products and materials, conventional Life Cycle Assessment (LCA) processes were not deemed feasible. Therefore, a streamlined, four- step methodology was developed. This incorporates the estimation approach for products [68].

First, information on the embodied energy coefficients for primary raw materials and finished products was compiled, when available. The embodied energy coefficient was not available for most of the donated products. Since the products were composed of primary raw materials that went through a series of manufacturing processes, the bills of materials and the manufacturing processes for sampled products were collected from the product manufacturer's websites, and patent documents. Environmental Product Declarations and Climate Declarations, documents published by manufacturers from Europe and Japan for the users to make purchase decisions based on the environmental performance of the product, provided information on electric power, fossil fuel, and water; emissions into air and water; usage and maintenance phase energy and material consumption; and $\mathrm{CO}_{2}$ emissions at production, usage and disposal phases [69]. The literature provided information on manufacturing processes including conventional metal manufacturing processes like machining, milling, grinding, 
casting, forging, and other processes in plastic, composite and nano-material manufacturing [66] [69]-[75].

Second, the information on the donated products from the Home Depot database was systematically sampled, reviewed, and then categorized, initially into 170 subcategories, and then further consolidated into 23 categories based on primary materials.

Third, detailed information for those products without coefficients from the first step was collected to fill in gaps in the data. This third step included evaluating the Bill of Materials and life cycle inventory resources based on Ganzheitliche Bilanz $(\mathrm{GaBi}) 4.0$ databases to identify representative materials and process flows. The GaBi database (developed by PE International;

http://www.gabi-software.com) is a modeling, reporting, and diagnostic software tool for LCA researchers and practitioners focusing on product sustainability performance during design and planning. The lifecycle inventory spans several industries and sectors.

Fourth, the embodied energy was calculated by assigning embodied energy coefficient values in MJ/kg to the appropriate SKUs in the given categories and multiplying them by the weight and quantity for each SKU. The calculated products were summed across categories in order to estimate the total embodied energy. The energy coefficients are commonly found in terms of $\mathrm{MJ} / \mathrm{kg}$ (Mega Joules/kilogram), $\mathrm{MJ} / \mathrm{L}, \mathrm{MJ} / \mathrm{m}^{2}, \mathrm{MJ} / \mathrm{m}^{3}, \mathrm{MMBtu} / \mathrm{ft}^{2}$, and $\mathrm{kWh} / \mathrm{unit}$. All the units were converted to $\mathrm{MJ} / \mathrm{kg}$ before doing the final analysis. To convert the non-standard units to $\mathrm{MJ} / \mathrm{kg}$, research on the average density of the products was necessary. This was found primarily from The Home Depot website (http://www.homedepot.com/) based on the products donated and calculated the average density. The final energy values are given in $\mathrm{kWh}$ (kilowatt-hours) and $\mathrm{MT} \mathrm{CO}_{2} \mathrm{Eq}$ (Metric Tonnes $\mathrm{CO}_{2}$ Equivalent). The U. S. EPA Interactive Units Convertor available under the Coalbed Methane Outreach Program was used to do unit conversions (https://www.epa.gov/cmop/units-converter).

Embodied Energy $=$ Weight ${ }^{*}$ Total Donated Quantity ${ }^{*}$ Embodied Energy Coefficient (Equation (3))

Based on this process with the values summarized in Table 3, we estimated the total embodied energy to be $151,665,667 \mathrm{kWh}$ (546 TJ).

6) The Streamlined Process Approach to Life Cycle Assessment

In an effort to further expand the embodied energy analysis, a second method was also used. The Economic Input-Output Life Cycle Assessment [76] approach estimates the materials, energy resources, and emissions associated with economic activities throughout the product supply chain. Originally theorized and developed by Nobel Laureate in Economic Sciences Wassily Leontief [77], the method was later advanced by researchers at the Green Design Institute of Carnegie Mellon University and made publicly available in 1995 via an online software tool [76]. It has been accessed widely and utilized for various products, services, and infrastructure systems [78]. Rather than focus on individual, ite 
Table 3. Total Embodied Energy Values for Each Product Category (Estimation Method).

\begin{tabular}{|c|c|c|c|}
\hline Category \# & Category Name & Total Weight (tons) & $\begin{array}{c}\text { Total Embodied } \\
\text { Energy (kWh) }\end{array}$ \\
\hline 1 & $\begin{array}{l}\text { Additives \& } \\
\text { Adhesions }\end{array}$ & $4.49 \mathrm{E}+01$ & $6.78 \mathrm{E}+05$ \\
\hline 2 & Batteries & $1.82 \mathrm{E}+00$ & $3.40 \mathrm{E}+04$ \\
\hline 3 & $\begin{array}{l}\text { Cement Based } \\
\text { Products }\end{array}$ & $2.99 \mathrm{E}+02$ & $5.69 \mathrm{E}+05$ \\
\hline 4 & Ceramic Materials & $1.77 \mathrm{E}+03$ & $2.89 \mathrm{E}+06$ \\
\hline 5 & $\begin{array}{c}\text { Construction } \\
\text { Chemicals }\end{array}$ & $6.52 \mathrm{E}+01$ & $2.88 \mathrm{E}+05$ \\
\hline 6 & $\begin{array}{l}\text { Construction } \\
\text { Materials }\end{array}$ & $5.55 \mathrm{E}+02$ & $1.99 \mathrm{E}+06$ \\
\hline 7 & $\begin{array}{c}\text { Construction Natural } \\
\text { Materials }\end{array}$ & $3.37 \mathrm{E}+02$ & $5.95 \mathrm{E}+05$ \\
\hline 8 & $\begin{array}{c}\text { Electrical \& Electronic } \\
\text { Products }\end{array}$ & $1.19 \mathrm{E}+03$ & $1.68 \mathrm{E}+07$ \\
\hline 9 & Electrical Cables \& Wires & $6.02 \mathrm{E}+01$ & $3.95 \mathrm{E}+05$ \\
\hline 10 & Fiberglass & $1.41 \mathrm{E}+02$ & $1.20 \mathrm{E}+06$ \\
\hline 11 & Glass Products & $1.39 \mathrm{E}+03$ & $7.63 \mathrm{E}+06$ \\
\hline 12 & Metal Plastic Products & $3.97 \mathrm{E}+02$ & $4.18 \mathrm{E}+06$ \\
\hline 13 & $\begin{array}{l}\text { Metal Plastic Wood } \\
\text { Products }\end{array}$ & $1.66 \mathrm{E}+02$ & $8.17 \mathrm{E}+06$ \\
\hline 14 & Metal Products & $1.78 \mathrm{E}+03$ & $4.18 \mathrm{E}+06$ \\
\hline 15 & Metal Rubber Products & $8.10 \mathrm{E}+00$ & $2.17 \mathrm{E}+05$ \\
\hline 16 & Natural Products & $1.85 \mathrm{E}+03$ & $3.12 \mathrm{E}+07$ \\
\hline 17 & Organic Products & $3.31 \mathrm{E}+02$ & $3.22 \mathrm{E}+05$ \\
\hline 18 & Paints & $8.20 \mathrm{E}+00$ & $1.76 \mathrm{E}+05$ \\
\hline 19 & Paper Cardboard Products & $3.97 \mathrm{E}+00$ & $2.43 \mathrm{E}+04$ \\
\hline 20 & Plastic Products & $1.11 \mathrm{E}+03$ & $2.52 \mathrm{E}+07$ \\
\hline 21 & Rubber Products & $4.17 \mathrm{E}+01$ & $1.12 \mathrm{E}+07$ \\
\hline 22 & Wood Furniture & $8.96 \mathrm{E}+02$ & $2.23 \mathrm{E}+06$ \\
\hline 23 & Wood Products & $1.47 \mathrm{E}+03$ & $1.93 \mathrm{E}+07$ \\
\hline
\end{tabular}

mized, and detailed production processes for each step of product development like process-based LCA approaches, which can become convoluted and difficult for complex systems, the EIO-LCA addresses comprehensive economies involving aggregated industry sectors. This is framed by broad economic boundary conditions which lack the specificity of process-based models [76]. The EIOLCA models available for selection within the tool apply the EIO-LCA method to various national and state economies. Each model is comprised of national economic input-output models coupled with publicly available resource use and emissions data. Most nations create economic input-output models of their given economies to varying degrees of specificity and frequency. The U.S. EIO models (benchmark references) are created every five years and represent the 
transactions among some 400 industry sectors using the North American Industry Classification System (NAICS) or other generic categories. Uncertainties with data sources that are outdated or incomplete, and due to aggregated levels have been noted [76]. Findings from using the EIO-LCA tool provide insight into the relative impacts of different types of products, materials, services, or industries from resource extraction through final assembly. For this calculation we used the previously designated 170 product subcategories which represented the level of detail necessary to recode the products based on the EIO-LCA sectors. Based on these, 67 sectors were identified and included in the calculation in this EIO-LCA sectorial analysis. Using the EIO-LCA codes, and including the total number of products in each identified sector and the associated monetary values (\$64.7 million total) retrieved from the original Framing Hope database, values were input into the EIO-LCA model. Steps in the EIO-LCA process include choosing the model of the options provided, selecting the industry and the sector, selecting the level of economic activity, and selecting the effects to display, after which the model can be run. As an example of sectorial results, for a single run the model chosen was the US National Producer Price Model for 2002, the industry and sector chosen was "other plastics production manufacturing" and the value of the sectorial economic activity was put in as $\$ 9,409,810$, based on the summed values of the products donated in that category. For these model choices, the total estimated embodied energy for the "other plastics production manufacturing" sector was 140 TJ. Figure 5 provides an example of the results for this largest embodied energy category.

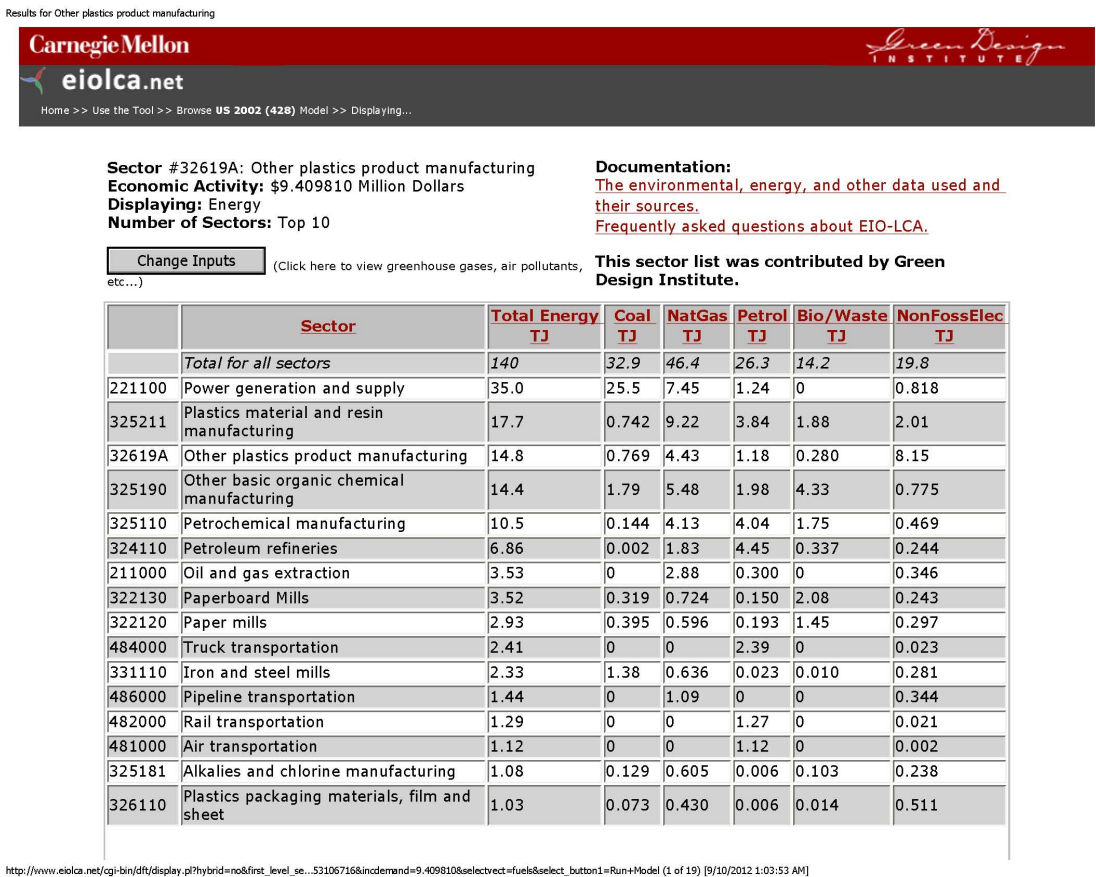

Figure 5. Embodied Energy EIO-LCA Example for "Other plastics product manufacturing" category. 
The model was run for each of the 67 selected EIO-LCA codes encompassing the range of donated products. A list of contributing industrial sectors and energy sources was output by the model. The total embedded energy for each run was recorded and summed for all of the product codes. Based on this approach, the total embodied energy was calculated to be $259,670,000 \mathrm{kWh}$ (935 TJ).

7) Question \#3: What is the Energy Conserved through Use of the Donated Products?

Most of the end users in the Framing Hope program qualify as low income and are in need of relief from the burden of high-energy costs. In fact, energy costs can pose serious hurdles to financial security for low-income families. Stakeholders in the lowest quintile spend about twice as much on energy as people in the highest quintile [77]. This energy cost disparity between socioeconomic groups is likely to increase as energy costs rise. In terms of energy efficient products, an important development in the United States has been implementation of the Energy Star program in 1992. This voluntary labeling program has been highly trusted and successful with over 20,000 private and public sector organizations. Studies of estimated savings based on the program's products vis-à-vis conventional products have found substantial energy and economic benefits [78].

As noted above, information from the Home Depot database allowed us to review and compile specific details for the donated products. With respect to establishing the energy conservation potential and energy consumption, some of the products had energy values associated with usage but most did not. By comparing the energy efficiencies of select donated products to those that were typically used by recipients of nonprofit services, estimates were determined for the energy savings attributable to the use of products. For calculating the energy savings of the Framing Hope Program, the Framing Hope Partner Survey [34] was used to make assumptions about the percentage of new products that would have otherwise been bought should the program have not existed. The survey provided feedback from participating nonprofit organizations regarding the usefulness of the products.

The total number of products initially examined for energy savings was 265,516 out of the nearly 4.7 million products donated. Estimates on energy usage for individual products were derived for 19,268 donated products, most of which were Energy Star certified. This allowed use of Energy Star program standards, data, and calculator resources, as developed by USDOE and USEPA (http://www.energystar.gov/). The main product categories investigated included appliances, ceiling fans, doors, insulation, light bulbs, light fixtures, skylights, and windows. Each category was individually analyzed. Estimates were calculated for behavioral changes related to a subset of donated products which could be directly linked to energy saving behaviors, like using less air conditioning when a ceiling fan is installed. These energy savings accrue when the usage or installation of the products result in a reduction in energy expenditures for 
the consumer. Specific products that fall into this category include insulation, windows, doors, and ceiling fans. Important considerations in the behavioral analysis included whether the products were used in retrofitting or new construction projects as well as geographical region.

A summary of products, energy savings, and monetary values are included in Table 4. Based on the analysis of the individual categories of products and range of values, the annual consumption of energy savings was estimated to be $3,378,319 \mathrm{kWh}$ (estimated value of $\$ 645,761$ ). Over the lifetime of the products, the energy savings were estimated to be $41,067,206 \mathrm{kWh}$ (estimated value of $\$ 5,408,924)$.

\section{Discussion and Conclusions}

This effort provides the first analysis of the potential sustainability-related benefits that accrue to a corporate product philanthropy program. The benefits include corporate as well as community and global benefits. The main corporate benefits are the cost savings that come from reduced landfill tipping fees, but also include a positive community image as well as tax savings. The community benefits are more varied, and include saved landfill space and reduced energy costs due to use of more energy efficient appliances and products as well as the reduced energy costs that result from using products, like insulation and ceiling fans, that encourage more energy efficient home heating and cooling behaviors. The global benefits result from the energy saved by reducing the amount of products manufactured when products are used rather than thrown in a landfill

Table 4. Summary of Product Categories, Total Annual Energy Savings, and Monetary Savings.

\begin{tabular}{ccc}
\hline Product Category & $\begin{array}{c}\text { Annual Energy Savings } \\
(\mathrm{kWh})\end{array}$ & $\begin{array}{c}\text { Annual Monetary } \\
\text { Savings (\$) }\end{array}$ \\
\hline Clothes Washer (Electric/Gas) & $5330 / 2345$ & $613 / 270$ \\
Dishwashers (Electric/Gas) & $11985 / 2023$ & $1378 / 233$ \\
Dehumidifiers & 10230 & 1176 \\
Air Purifiers & 12436 & 1430 \\
Ceiling Fans & $140078 / 6570536$ & $17451 / 1028426$ \\
(Technical/Behavioral) & 39808 & 4776 \\
Doors & 78292 & 9000 \\
Insulation & 238260 & 26321 \\
Light Bulbs & 588370 & 64897 \\
Light Fixtures & 6058 & 697 \\
Skylights & $38524 / 168786$ & $4686 / 22140$ \\
Windows &
\end{tabular}

*For ceiling fans, technical savings are based on energy efficiencies of Energy Star versus non-Energy Star products; and behavioral savings include savings from setting air conditioning thermostat higher $(\sim 4 \mathrm{de}-$ gree difference). 
when the products reach the end of their salable or marketable "shelf life."

These results provide an indication of the relative magnitude of environmental, economic, and energy benefits associated with the array of donated products in the Framing Hope program. With the shift in corporate policy and operations, more than $30,000 \mathrm{yd}^{3}$ of landfill space was saved and over $\$ 700,000$ of waste tipping fees were not spent. Calculations based on both national averages and more refined state level data demonstrate that significant savings were derived from the Framing Hope program. Considering the concerns associated with landfilling of solid waste including hazards associated with fire, potential disease vectors (animals and insects), uncontrolled release of gases, emissions of greenhouse gases, releases of leachate that have the potential for adverse effects on surface and groundwater resources, increased levels of electronic waste, odor, and aesthetics [54] [79] [80], programs such as Framing Hope represent important interventions toward increased public safety, improved environmental health, and more sustainable communities.

Two lifecycle approaches were used to calculate the embodied energy associated with the donated products. The modified LCA process involved far more assumptions and uncertainties with respect to underlying materials and production processes compared to the economic input output technique whereby the product data coding was closely aligned with the sector categories contained in the EIO-LCA model. Although the results are varied by somewhat less than a factor of two between the two methods, these differences are not unexpected based on the different levels of data confidence. There is value added in measuring and analyzing energy from disparate perspectives. Both approaches determined that significant energy was embedded in the donated products representing a substantial opportunity cost linked to product management decisions.

Of the three research questions, evaluations of avoided energy effects presented the greatest challenge. This was partly due to the relatively small number of products that were certified as energy efficient (i.e., Energy Star) with well-defined calculators and guidance to determine energy savings. Additionally, metric uncertainties with respect to individual level behaviors and use, types of construction projects, and geographic regions presented difficult complications. Thus, the calculations and results obtained were a positive step but further investigation is suggested.

These findings demonstrate that the Framing Hope program has had a positive impact on community sustainability. With the enhanced focus on lifecycle product management and resource efficiency along the supply chain for retail business, partnerships with local nonprofits are able benefits of corporate programs.

\section{Acknowledgements}

This research has been partially funded by Indiana University Office of Sustai- 
nability (IUOS), Environmental Research \& Education Foundation (EREF), Kansas State University Center for Hazardous Substance Research (CHSR), and Consortium for Environmental Stewardship and Sustainability (CESAS).

\section{References}

[1] Heuer, M. (2011) Ecosystem Cross-Sector Collaboration: Conceptualizing an Adaptive Approach to Sustainability Governance. Business Strategy and the Environment, 20, 211-221. https://doi.org/10.1002/bse.673

[2] Hubbard, G. (2009) Measuring Organizational Performance: Beyond the Triple Bottom Line. Business Strategy and the Environment, 18, 177-191.

https://doi.org/10.1002/bse.564

[3] Portney, K. and Cuttler, Z. (2010) The Local Nonprofit Sector and the Pursuit of Sustainability in American Cities: A Preliminary Exploration. Local Environment, 15, 323-339. https://doi.org/10.1080/13549831003677704

[4] Sachs, J.D. (2015), The Age of Sustainable Development. Columbia University Press, New York. https://doi.org/10.7312/sach17314

[5] Waddell, S. (2000) A "Win-Win" Role for Civil Society in Business Strategy. Journal for Nonprofit Management, 4, 24-43.

[6] Loza, J. (2004) Business-Community Partnerships: The Case for Community Organization Capacity Building. The Journal of Business Ethics, 53, 297-311. https://doi.org/10.1023/B:BUSI.0000039415.90007.56

[7] Austin, J. (2000) Strategic Collaboration between Nonprofits and Businesses. Nonprofit and Voluntary Sector Quarterly, 29, 69-97. https://doi.org/10.1177/0899764000291S004

[8] Chaskin, R., Brown, P., Venkatesh, S. and Vidal, A. (2001) Building Community Capacity. Aldine De Gruyter, New York.

[9] Delfin, F.G. and Tang, S. (2008) Foundation Impact on Environmental Nongovernmental Organizations: The Grantees' Perspective. Nonprofit and Voluntary Sector Quarterly, 37, 603-625. https://doi.org/10.1177/0899764007312667

[10] Kelly, C.C.M (2011) Understanding Accountability in Social Enterprise Organisations: A Framework. Social Enterprise Journal, 7, 224-237. https://doi.org/10.1108/17508611111182386

[11] Milen, A. (2001) What Do We Know about Capacity Building: An Overview of Existing Knowledge and Good Practice. Department of Health Service Pro Vision. World Health Organization, Geneva.

[12] Nikolaou, I.E., Evangelinos, K.I. and Allan, A. (2013) A Reverse Logistics Social Responsibility Evaluation Framework Based on the Triple Bottom Line Approach. Journal of Cleaner Production, 56, 173-184.

[13] Perrini, F., Russo, A., Tencati, A. and Vurro, C. (2011) Deconstructing the Relationship between Corporate Social and Financial Performance. Journal of Business Ethics, 102, 59-76. https://doi.org/10.1007/s10551-011-1194-1

[14] Phillips, W., Lee, H., Ghobadian, A., O’Regan, N. and James, P. (2014) Social Innovation and Social Entrepreneurship A Systematic Review. Group and Organization Management, 40, 428-461.

[15] Zhang, D.D. and Swanson, L.A. (2013) Social Entrepreneurship in Nonprofit Organizations: An Empirical Investigation of the Synergy between Social and Business Objectives. Journal of Nonprofit and Public Sector Marketing, 25, 105-125. 
https://doi.org/10.1080/10495142.2013.759822

[16] Agyeman, J. and Evans, B. (2003) Toward Just Sustainability in Urban Communities: Building Equity Rights with Sustainable Solutions. The Annals of the American Academy of Political and Social Science, 590, 35-53. https://doi.org/10.1177/0002716203256565

[17] Bashour, H., Bellows, L., Krishnan, B., LaBeau, K., Lindeen, L., Rog, V., Smothers, L., Summers, L., Wendelin, M.B. and Vahnie, E. (2010) Assessing Product Philanthropy's Impact on Community Sustainability: Energy and Solid Waste. Indiana University School of Public and Environmental Affairs Capstone Papers.

[18] Carnegie, A. (1899) Wealth. The North American Review, 148, 653-664.

[19] Friedman, M. (1970) The Social Responsibility of Business Is to Increase Its Profits. New York Times Magazine, September 13, 32-33.

[20] Young, D.R. and Burlingame, D.F. (1996) Paradigm Lost: Research toward a New Understanding of Corporate Philanthropy. Corporate Philanthropy at the Crossroads, 158-176.

[21] Illingworth, P., Pogge, T. and Wenar, L. (2011) Giving Well: The Ethics of Philanthropy. Oxford University Press, New York. https://doi.org/10.1093/acprof:oso/9780199739073.001.0001

[22] Johnson, O. (1966) Corporate Philanthropy: An Analysis of Corporate Contributions. The Journal of Business, 39, 489-504. https://doi.org/10.1086/294890

[23] Wang, H. and Qian, C. (2011) Corporate Philanthropy and Corporate Financial Performance: The Roles of Stakeholder Response and Political Access. Academy of Management Journal, 54, 1159-1181. https://doi.org/10.5465/amj.2009.0548

[24] Bowen, H.R. (1953) Social Responsibilities of the Businessman. Harper and Row, New York.

[25] Carroll, A. (1991) The Pyramid of Corporate Social Responsibility: Toward the Moral Management of Organizational Stakeholders. Business Horizons, 34, 39-48.

[26] Brammer, S. and Millington, A. (2005) Corporate Reputation and Philanthropy: An Empirical Analysis. Journal of Business Ethics, 61, 29-44.

https://doi.org/10.1007/s10551-005-7443-4

[27] Chen, J.C., Patten, D. and Roberts, R. (2008) Corporate Charitable Contributions: A Corporate Social Performance or Legitimacy Strategy? Journal of Business Ethics, 82, 131-144.

Foster, M.K., Meinhard, A.G., Berger, I.E. and Krpan, P. (2009) Corporate Philanthropy in the Canadian Context: From Damage Control to Improving Society. Nonprofit and Voluntary Sector Quarterly, 38, 441-466.

[28] Halme, M. and Laurila, J. (2009) Philanthropy, Integration or Innovation? Exploring the Financial and Societal Outcomes of Different Types of Corporate Responsibility. Journal of Business Ethics, 84, 325-339. https://doi.org/10.1007/s10551-008-9712-5

[29] Nicholls, A. (2009) “We Do Good Things, Don't We?": "Blended Value Accounting” in Social Entrepreneurship. Accounting, Organizations and Society, 34, 755-769.

[30] Patten, D. (2008) Does the Market Value Corporate Philanthropy? Evidence from the Response to the 2004 Tsunami Relief Effort. Journal of Business Ethics, 81, 599-607. https://doi.org/10.1007/s10551-007-9534-X

[31] Ricks, J. and Williams, J. (2005) Strategic Corporate Philanthropy: Addressing Frontline Talent Needs through an Educational Giving Program. Journal of Busi- 
ness Ethics, 60, 147-157. https://doi.org/10.1007/s10551-005-1175-3

[32] Bhattacharya, C., Sen, S. and Korschun, D. (2008) Using Corporate Social Responsibility to Win the War for Talent. MIT Sloan Management Review, 49, 37-44.

[33] Gazley, B. and Abner, G. (2014) Evaluating a Product Donation Program: Challenges for Charitable Capacity. Nonprofit Management and Leadership, 24, 337-355. https://doi.org/10.1002/nml.21094

[34] Luo, X. and Bhattacharya, C. (2006) Corporate Social Responsibility, Customer Satisfaction, and Market Value. Journal of Marketing, 70, 1-18. https://doi.org/10.1509/jmkg.70.4.1

[35] Nidumolu, R., Prahlad, C. and Rangaswami, M. (2009) Why Sustainability Is Now the Key Driver of Innovation. Harvard Business Review, 87, 56-64.

[36] Porter, M. and Kramer, M. (2011) Creating Shared Value. Harvard Business Review, 89, 62-77.

[37] Austin, J. and Seitanidi, M. (2012) Collaborative Value Creation: A Review of Partnering between Nonprofits and Businesses: Part I. Value Creation Spectrum and Collaboration Stages. Nonprofit and Voluntary Sector Quarterly, 41, 726-758. https://doi.org/10.1177/0899764012450777

[38] Harris, M. (2012) Nonprofits and Business: Toward a Subfield of Nonprofit Studies. Nonprofit and Voluntary Sector Quarterly, 41, 892-902.

https://doi.org/10.1177/0899764012443735

[39] National Center for Charitable Statistics (NCSS) (2010) The Nonprofit Almanac 2010: Number of Nonprofit Organizations by State. Washington DC Urban Institute.

[40] Giving USA (2012) The Annual Report on Philanthropy for the Year 2011. The Center on Philanthropy at Indiana University.

[41] Jackson, P.J. (2006) Charitable Contributions of Food Inventory: Proposals for change. Congressional Research Service: Library of Congress.

[42] Chronicle of Philanthropy (2012) Special Report: How American Gives. The Chronicle of Philanthropy, 24, August 23, 2012.

https://www.philanthropy.com/specialreport/how-america-gives-2014/1?CID=cpw directory_data

[43] Lim, T. (2009) Measuring the Value of Corporate Philanthropy: Social Impact, Business Benefits, and Investor Returns. Committee for Encouraging Corporate Philanthropy, New York.

[44] Committee Encouraging Corporate Philanthropy (CECP) (2011) Giving in Numbers 2010 Edition. Corporate Giving Standard, New York.

[45] Ross, J. and McGiverin-Bohan, K. (2011) The Business Case for Product Philanthropy. Indiana University School of Public and Environmental Affairs.

[46] Good360 (2012) The Framing Hope Product Donation Program: Partnering Home Depot Stores with Local Non Profit Organizations. The Home Depot Foundation, Atlanta.

[47] Hansen, S., Dunford, B., Boss, A., Boss, R. and Angermeier, I. (2011) Corporate Social Responsibility and the Benefits of Employee Trust: A Cross-Disciplinary Perspective. Journal of Business Ethics, 102, 29-45. https://doi.org/10.1007/s10551-011-0903-0

[48] Edelman (2010) Citizens Engage! Edelman Goodpurpose Study 2010 4th Annual Global Consumer Survey. 
[49] Williams, R. and Barrett, J. (2000) Corporate Philanthropy, Criminal Activity, and Firm Reputation: Is there a link? Journal of Business Ethics, 26, 341-350. https://doi.org/10.1023/A:1006282312238

[50] Paarlberg, L.E. and Meinhold, S. (2012) Using Institutional Theory to Explore Local Variations in United Way's Community Impact Model. Nonprofit and Voluntary Sector Quarterly, 41, 826-849. https://doi.org/10.1177/0899764011418123

[51] U.S. Census Bureau (2009) Consumer Expenditure Survey 2009. Collected by the U.S. Bureau of Labor Statistics. http://www.bls.gov/cex/

[52] Seefeldt, K. and Abner, G. (2011) Framing Hope End User Pilot Study. Indiana University School of Public and Environmental Affairs. Indiana University.

[53] U.S. Environmental Protection Agency (USEPA) (2011) Municipal Solid Waste Generation, Recycling, and Disposal in the United States: Facts and figures for 2010. Solid Waste and Emergency Response. EPA-530-F-11-005.

[54] Clark, C., Jambeck, J. and Townsend, T. (2006) A Review of Construction and Demolition Debris Regulations in the United States. Critical Reviews in Environmental Science and Technology, 36, 141-186. https://doi.org/10.1080/10643380500531197

[55] U.S. Environmental Protection Agency (USEPA) (1998) Characterization of Building-Related Construction and Demolition Debris in the United States. Office of Solid Waste. EPA530-R-98-010.

[56] Agency for Toxic Substances and Disease Registry (ATSDR) (2003) Exposure Investigation: Hydrogen Sulfide Exposure in Warren Township, Trumbull County, Ohio. U.S. Department of Health and Human Services, Public Health Service, Atlanta.

[57] Agency for Toxic Substances and Disease Registry (ATSDR) (2014) Toxicological profile for Hydrogen Sulfide/Carbonyl Sulfide (Draft for Public Comment). U.S. Department of Health and Human Services, Public Health Service, Atlanta.

[58] Colledge, M. and Wilder, L. (2008) Construction and Demolition (CandD) Landfills: Emerging Public and Occupational Health Issues. Journal of Environmental Health, 71, 50-52.

[59] Dixon, N. and Jones, D.R.V. (2005) Engineering Properties of Municipal Solid Waste. Geotextiles and Geomembranes, 23, 205-233.

[60] Hudson, A.P., White, J.K., Beaven, R.P. and Powrie, W. (2004) Modelling the Compression Behaviour of Landfilled Domestic Waste. Waste Management, 24, 259-269.

[61] Machado, S.L., Carvalho, M.F. and Vilar, O.M. (2002) Constitutive Model for Municipal Solid Waste. Journal of Geotechnical and Geoenvironmental Engineering, 128, 940-951. https://doi.org/10.1061/(ASCE)1090-0241(2002)128:11(940)

[62] Van Haaren, R., Goldstein, N. and Themelis, N.J. (2010) The State of Garbage in America. BioCycle, 49, 16-23.

[63] Waste360.com (2010).

[64] Costanza, R. (1980) Embodied Energy and Economic Values. Science, 210, 1219-1224. https://doi.org/10.1126/science.210.4475.1219

[65] Sahni, S., Boustani, A., Gutowsk, T. and Graves, S. (2010) Furniture Remanufacturing and Energy Savings. Environmentally Benign Laboratory. Laboratory for Manufacturing and Productivity. Sloan School of Management. MITEI-1-e-2010.

[66] U.S. Environmental Protection Agency (USEPA) (2008) Wire and Cable Insulation and Jacketing: Life-Cycle Assessments for Selected Application. Office of Pollution Prevention and Toxics, Design for the Environment. EPA-744-S-08-001.

[67] Ricoh Co. Ltd. (2000) Environmental Product Declaration Ricoh Imagio MF6550 
Digital Copier Main Unit. Registration Number: S-EP-00004.

http://www.environdec.com/en/Articles/EPD/Ricoh-first-with-a-global-Type-III-en vironmental-declaration/

[68] Duque Ciceri, N., Gutowski, T.G. and Garetti, M. (2010) A Tool to Estimate Materials and Manufacturing Energy for a Product. IEEE International Symposium on Sustainable Systems and Technology, 1-6. http://ieeexplore.ieee.org/xpl/mostRecentIssue.jsp?punumber $=5496818$

[69] Blanchard, S. and Reppe, P. (1998) Life Cycle Analysis of a Residential Home in Michigan. Center for Sustainable System and School of Natural Resources and Environment, University of Michigan. http://www.p2pays.org/ref/37/36507.pdf

[70] Grondzik, W., Kwok, A., Stein, B. and Reynolds, J. (2010) Mechanical and Electrical Equipment for Buildings. John Wiley and Sons, Hoboken.

[71] Lawson, B. and Rudder, D. (1996) Building Materials Energy and the Environment: Towards Ecologically Sustainable Development. Royal Australian Institute of Architects.

[72] Nishimura, K., Hondo, H. and Uchiyama, Y. (1995) Derivation of Energy-Embodiment Functions to Estimate the Embodied Energy from the Material Content. Energy, 21, 1247-1250.

[73] Procurement, G.P. (2010) Thermal Insulation Technical Background Report. European Commission.

http://www.vergabebrief.de/wp-content/uploads/2014/09/Background_Report_The rmal-Insulation.pdf

[74] U.S. Department of Energy (USDOE) (2009) Buildings Energy Data Book (2009 BEDB). Office of Energy Efficiency and Renewable Energy. http://buildingsdatabook.eren.doe.gov/DataBooks.aspx

[75] Carnegie Mellon University Green Design Institute (CMU-GDI) (2008) Economic Input-Output Life Cycle Assessment (EIO-LCA), US 1997 Industry Benchmark Model. http://www.eiolca.net

[76] Leontief, W. (1938) The Significance of Marxian Economics for Present-Day Economic Theory. The American Economic Review, 28, 1-9.

[77] Hendrickson, C., Lave, L. and Matthews, H. (2006) Environmental Life Cycle Assessment of Goods and Services: An Input-Output Approach. Resources for the Future Press, Washington DC.

Podesta, J. and Miller, S. (2009) Seizing the Energy Opportunity. Pathways, Fall, 14-18.

[78] Sanchez, M., Webber, C., Brown, R. and Homan, G. (2008) Status Report. Savings Estimates for the ENERGY STAR ${ }^{\oplus}$ Voluntary Labeling Program. Lawrence Berkeley National Laboratory. LBNL-56380, Berkeley.

[79] Tchobanoglous, G., Thiesen, H. and Vigil, S. (1993) Integrated Solid Waste Management: Engineering Principles and Management Issues. McGraw-Hill, New York.

[80] American Society of Civil Engineers (ACSE) (2009) Report Card for America's Infrastructure, Water and Environment-Solid Waste. ASCE Press, Reston. 
Submit or recommend next manuscript to SCIRP and we will provide best service for you:

Accepting pre-submission inquiries through Email, Facebook, LinkedIn, Twitter, etc. A wide selection of journals (inclusive of 9 subjects, more than 200 journals)

Providing 24-hour high-quality service

User-friendly online submission system

Fair and swift peer-review system

Efficient typesetting and proofreading procedure

Display of the result of downloads and visits, as well as the number of cited articles Maximum dissemination of your research work

Submit your manuscript at: http://papersubmission.scirp.org/

Or contact jep@scirp.org 